University of Nebraska - Lincoln

DigitalCommons@University of Nebraska - Lincoln

Faculty Publications: Department of Teaching, Department of Teaching, Learning and Teacher Learning and Teacher Education

Education

$5-1-2000$

\title{
Learning to Look through the Eyes of Our Students: action research as a tool of inquiry
}

Joanne Arhar

Kent State University, jarhar@kent.edu

Gayle A. Buck

University of Nebraska-Lincoln, gabuck@indiana.edu

Follow this and additional works at: https://digitalcommons.unl.edu/teachlearnfacpub

Part of the Teacher Education and Professional Development Commons

Arhar, Joanne and Buck, Gayle A., "Learning to Look through the Eyes of Our Students: action research as a tool of inquiry" (2000). Faculty Publications: Department of Teaching, Learning and Teacher Education. 4.

https://digitalcommons.unl.edu/teachlearnfacpub/4

This Article is brought to you for free and open access by the Department of Teaching, Learning and Teacher Education at DigitalCommons@University of Nebraska - Lincoln. It has been accepted for inclusion in Faculty Publications: Department of Teaching, Learning and Teacher Education by an authorized administrator of DigitalCommons@University of Nebraska - Lincoln. 


\title{
Learning to Look through the Eyes of Our Students: action research as a tool of inquiry
}

\author{
JOANNE ARHAR \\ Kent State University, USA \\ GAYLE BUCK \\ University of Nebraska-Lincoln, USA
}

\begin{abstract}
The story we are about to tell occurred when Gayle was a middle school science teacher and graduate student in Joanne's seminar on the study of teaching. Gayle was trying to make sense of her science students' indifference toward the environment, an attitude that concerned her as an environmentalist. She turned her inquiry into an action research project that sought to answer the question, 'What are the assumptions that my middle school students have about their relationship with the environment?' Joanne was mentoring Gayle in her action research study, and at the same time exploring Gayle's perspective as an action researcher. Now, several years later, we are both action researchers and teacher educators and understand that we have been looking through the eyes of our students in order to become scholars of our own teaching.
\end{abstract}

\section{Action Research and Self-Reflection}

We believe that good teaching is characterised by an attitude of scientific inquiry. As such, it is a form of scholarship in which we ask: 'How can I improve my practice?' (Whitehead, 1989). We try out some ideas in response to that question, systematically observe and collect evidence as a consequence of those actions, and analyse and reflect on the evidence. Action research follows this same cyclical process of acting, observing, and critical reflection on the consequences of our actions (see Figure 1).

Our aim as action researchers is to improve our teaching by using professional (informed) eyes to observe our own practice (Arhar et al, 2001). We collaborate with others, including our students, to enhance the power of 
our learning. We face the challenges we meet with action and analysis, sharing the results for the larger community to critique.

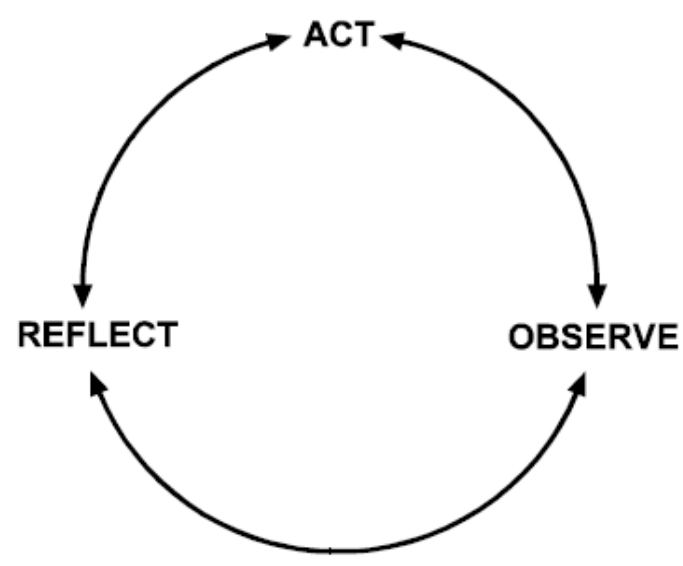

Figure 1.

Not only is teaching a form of scientific inquiry, it is a moral commitment to the democratic relationships between teachers and learners (Tom, 1984). For John Dewey, this commitment means shaping a learning community that values both the social welfare of its students and their development as human beings. These communities develop as we deliberate and negotiate common aims, beliefs and knowledge. The oneness that comes with this shared understanding is accompanied by respect for alternative perspectives (Dewey, 1964).

Unlike other forms of inquiry, action research is geared toward improving the researcher, as well as the research situation and research participants. The philosopher, Sartre, conceptualises research as a process undertaken by intellectuals, persons whose 'minds watch themselves'. Furthermore, 'Action researchers design their watching into their work, not only as an after-thought ... but as a documented reflective process throughout. This is the important "selfcritical" part of Lawrence Stenhouse's definition [of research]' (Arhar et al, 2001). Thus, looking through our students' eyes is more than a passing interest. It is our belief that gaining the perspective of our students is the foundation of democratic and collaborative relationships with those whose education we shape, and a means of self-awareness. This was not all clear to us when we first began working together. ...

As we began to explore ways to design the study, Joanne suggested that Gayle address a series of questions (see Arhar et al, 2001).

What is your research interest? What are the values that motivate your study?

How will you address your question? 
How will you document the process?

How will you interpret the data?

How will you verify your interpretations?

What will you do next and how will these actions make life better?

How will you make this public?

As you will see, Gayle addressed these questions as she wrote up her study which focuses on ways she, as a middle school science teacher, learned about her students' perspectives on the environment and their relationship to it.

\section{Learning to Look at the Environment and Environmental Education through the Eyes of Middle Level Students}

What formal education has to do is to produce people who are fit to be inhabitants of the planet. [Otherwise] young people are going to grow up and discover that we have taught them how to live in a world long gone-Kenneth Boulding. (As cited in A Guide to Curriculum Planning in Environmental Education, 1985)

\section{What is My Research Interest?}

I (Gayle) came across the above quote very early in my teaching career. It thoroughly summed up what I felt was the purpose of science education. I committed myself to preparing my students to be fit inhabitants of the planet. As a teacher at a maths/science/environmental alternative school, I integrated maths and science within the context of environmental education. I eagerly enrolled in workshops and courses and read everything I could to help me prepare my lessons. I was confident that I was making an impact. I quickly discovered, much to my dismay, that the impact I was making was not what I had envisioned.

That realisation came as I was looking over a set of photographs of the students from my recycling team. This team consisted of a group of fifthgrade students who volunteered to stay after school and give up some of their recess time to learn about recycling, and to take part in recycling projects for the school and community. I was so proud of that team and the many awards they had won. The photographs pictured my students in front of mounds of plastic jugs, glass jars and aluminum cans they had collected. Seemingly, the prizes and positive comments I offered paid off. However, I recalled one student's story about dumping soda pop down the drain because she needed that plastic bottle to fill a quota! Was that what I wanted to teach my students? I then began to seriously question my students about what they were learning. They gave me facts and definitions about recycling and the environment that seemed to be nothing more than a regurgitation of what I had taught, but I suspected that they were taking 
part in conservation activities only because I directed them to. They could not explain how all of their work was preparing them to be better inhabitants of the planet.

My teaching changed drastically after that realisation. I completely halted all environmental education programmes and nearly all related lessons. However, my personal belief that formal education has to produce people who are fit to be inhabitants of the planet did not waver. I just did not yet know how to accomplish my goal. This desire fueled my quest. My first break through came from Daniel Quin's Ishmael (1993), which prompted me to question some of the assumptions our culture fosters about our relationship with the environment. Over the course of a year and a half, I read many more books about environmental education Educating for an Ecologically Sustainable Culture by C. A. Bowers (1993), The Web of Life by Fritjof Capra (1996) and Ecological Literacy by David Orr (1992), to name a few. I realised that people have to do more than question their actions. They also have to question their assumptions about their relationship with nature. Without questioning assumptions, any changes will be superficial and short-lived, and we will continue to act in ways that will be harmful to our environment and ourselves.

With this new understanding, my new teaching goals were to design ways for my students to explore their assumptions. I wanted to understand their perspective. Based on what I learned, I would then develop meaningful environmental education lessons that challenged my students to rethink their beliefs and to build habits of mind that would lead them to continue exploring their assumptions as they grew into adulthood. At this point in my career, I was now teaching eighth-grade integrated science in a different school and was a graduate student in Joanne's research class. We discussed various ways to address my research interest. Action research with its emphasis on improving practice and supporting democratic relationships seemed to be a potent way for me to inquire into my students' assumptions.

\section{How Did I Address My Question?}

My question was 'What are the assumptions that my middle school students have about their relationship with the environment?' My research method was simple. I would begin by clarifying the meaning of 'assumption', provide an example, and then ask my middle level students what their assumptions were about their relationship with the environment. I was ready with chalk in hand to list a plethora of assumptions on the board. I would then record those assumptions, categorise them, and look for patterns. I was disappointed when what I heard were definitions and comments that seemed to come straight from Time magazine. I rephrased my question about fifteen different ways and worked hard to explain what I was looking for. They, in turn, were trying really hard to give me the answers they 
thought I would want. This first attempt failed miserably and I needed another plan.

I began to wonder if adolescents even have assumptions about their relationship with the environment. Did they have a set of beliefs that guided their actions, or did they just do as they were told? After much reflection, I realised that my direct questioning was not working because it is difficult (if not impossible) to discover assumptions that are encultured in us. These assumptions aren't packaged in blinking red lights that shout out to us. I would have to listen carefully to my students and interpret what they were saying. Listening to their discussions about the environment was the second phase of my evolving design.

I shared with my students my research question and my ideas about using focus group interviews. I offered students the choice of participating in either an audio taped or a non-audio taped focus group. I feared that no one would want to participate, but nearly every student returned a signed permission form indicating parental approval to participate in the taped interviews. I credit the high return rate to the fact that I had made them a part of the research process: they wanted to find out the results as much as I did.

As a class, we generated a list of environmental questions that were important to them. These questions were as follows: (a) Should hunting be allowed? (b) Should people be allowed to use chemicals on their lawns? (c) Should we limit the population of people in the world? (d) Should we have to learn about the environment in school? I then formed several focus groups of four or five students, and scheduled them to meet at various places throughout the school. Each group had adult supervision (my insistence); however, that adult was not allowed to listen in on their conversation (their insistence). I placed a tape recorder at each group's table and gave the students control of turning it on and off. Because several students did not feel comfortable with their ideas being recorded, one group did not have a tape recorder. A student was appointed facilitator for each group. I directed the groups to discuss each question until they felt the group reached consensus or an impasse. It should be noted here that I used classroom discussions often. These students had previously worked on communication skills such as letting others finish their point, not attacking people and listening carefully. They didn't always stick to those rules, but I believe they were better prepared for this type of project because of those lessons and experiences. I walked around from group to group and briefly listened in to their discussions, trying not to influence its nature and direction.

At first, their talk was full of those same definitions and canned responses that characterised earlier discussions. However, after a few minor debates about the first question related to hunting, the students became less interested in the recorder and more interested in making their points known to their peers. Students then wrote in their journal about the discussion and debates that ensued. 


\section{How Did I Interpret the Data and Verify My Interpretations?}

I listened to each groups' tape several times, and read and reread student journal entries looking for underlying assumptions. Then I put the data away for a few days and let my mind wonder about what I had heard. I went back to the tapes and listened again, and this time I recorded what I thought were key statements from students. I then grouped these statements. I gathered several large pieces of poster paper and labelled each with one of the labels, and proceeded to list the quotes and journal entries that I believed belonged to that category.

Once the statements were grouped, I read through each grouping and determined if the statements fit that category or another one, or if, perhaps, a new category was warranted. I then looked for patterns in the categories. Did all the students have the same belief? Were there conflicting beliefs?

Once I categorised the data, looked for patterns and began to formulate their assumptions, I used those assumptions as the basis for additional journalwriting in which I confirmed, denied or reshaped my thinking related to student assumptions about the environment.

\section{What Did I Learn about My Students’ Assumptions?}

Three categories were developed from the data. These categories included:

(1) the value of the environment; (2) the management of the environment; and (3) caring about the environment. These categories revealed three general assumptions my students had about the environment. The following is a discussion of these assumptions.

Assumption 1: the environment is separate from themselves. The students had a very limited understanding of their connection to the environment. The students in this study felt there was, indeed, value in the environment. That value, however, was solely based on what the environment could provide them to make their lives more comfortable and entertaining. I was not surprised. However, I was surprised by the fact that they had a very limited idea about just how much their lives depended on the environment.

The discussion related to hunting provided illustrations of this assumption. Most students 'support hunting because a lot of people need food and it [hunting] supplies food for humans'. However, many students expanded this idea as the discussion proceeded to include the entertainment value of hunting. Statements such as, 'I think you guys should be able to hunt ... that's good and everything ... I don't know you guys just should. That's what you guys get your kicks out of ...'. Others shared this belief: 'It's a sport ... that's [deer head] a trophy'. Another adds, 'He conquered what he went out to do. It's like winning the world championship in basketball'.

I was not surprised by such ideas; however, their limited understanding of exactly what the environment did provide them surprised me. They valued the environment because it provided oxygen and meat from 
kills. However, these eighth-graders did not seem to truly understand the concept of natural resources, or even the simple fact that the food in the grocery store still came from the environment. Several comments were made such as 'I do support it [hunting] if a person can't afford to buy the meat and hunting is their last resort for survival'.

In all, the students' understanding of the environment centred on what's 'wild'. They did not see themselves as living in the environment and therefore did not value it.

Assumption 2: nature will literally collapse without human management. The students felt that people have to manage the environment. Without human management, the environment would not function.

I was not surprised that the students believed that the deer population had to be controlled by humans. These students came from a rural community where hunting programs were popular. The students expressed familiar sentiments such as 'if there's not hunting then there will be an overpopulation of deer and stuff and everyone will hit them with their cars ... '. However, I was surprised by their thoughts of what would happen to nature if we did not manage it. For example, the student in the previous example finished his statement by saying, 'if we don't hunt then all the population of the world will die'. Others elaborated: 'hunting controls the population because we kill the deer and their predators help us control it and if the deer were to overpopulate, the predators would overpopulate and what the deer eat would underpopulate because there would be so much of them [deer]. So, the fields and stuff would become solid dirt because all the deer would eat the grass if they were overpopulated ... there would be no vegetation and we would run out of oxygen'. This belief, that the natural world would fall apart without human management, was expressed throughout the discussions. Others added: 'You know how pinecones fall to the ground and you know how many survive that? None of them.' Another student finishes, 'those pinecones would not be able to survive if nobody would nurse them'.

When the discussion turned to human population, the students realised that society couldn't hunt humans. So, the conversation seemed to falter somewhat until someone mentioned that 'those' extra people would be competing for things the students want. And then more people means ... that there will be less oxygen for everyone else.' Another expressed, 'you know how like the US is a real powerful country. If we overpopulate then we won't have as much stuff for everyone.' Since the students reasoned that they couldn't hunt people, they were unsure of what to do about these extra people that would be taking their stuff. One group reasoned that the answer was to reduce the amount of money welfare pays for babies.

Assumption 3: it is not cool to express real interest in the environment (although many of them did secretly care). Their attitudes seemed to be connected to their perception of environmentalists. Some students thought an environmentalist was someone who cares for nature. One student 
summed it up by saying 'an environmentalist is a person who cares for the environment, recycles, and doesn't harm the Earth'. Another defined an environmentalist as 'someone who preserves nature and does not litter or use the land in a harmful way or who takes great concern for the environment and does his best to conserve and save it.' Others tended to think of someone more extreme. For these students, 'an environmentalist is a person that is totally obsessed with the well being of the environment. Tree huggers are an example.'

For the few students who initially considered themselves to be environmentalists, peer pressure was waiting. They started the conversation stating 'everybody in the world is an environmentalist'. However, when others quickly jumped in accusing environmentalists of being tree huggers, students were quick to defend themselves by denying their original affiliation. One girl mentioned that she had a cactus. Another said 'therefore you are [an environmentalist] ... because you're helping a plant survive. She quickly responded, No, I'm not! I just bought it [the cactus] because there's not enough oxygen in my room, I need oxygen.'

However, within the safety of their journals many students revealed that they did care about their environment. They made statements such as, 'I do consider myself an environmentalist because I do care about the environment. Yet, I don't do things like overreact when someone cuts down a tree.' Another wrote, 'On a small scale I consider myself an environmentalist because I do things around the house to conserve. But, I don't hug trees!'

\section{What Did I Learn about My Teaching?}

Looking at the environment through eighth-grade eyes was a very enlightening experience. The process revealed some beliefs that were really surprising for me. I knew adolescents are known to be egocentric in their thinking. Elkind (1981) explains adolescent egocentrism in terms of a move toward formal operational thought:

Formal operational though not only enables the adolescent to conceptualise his [sic] thought, it also permits him to conceptualise the thought of other people; his capacity, however, is the crux of adolescent egocentrism. This egocentrism emerges because, while the adolescent can now cognise the thoughts of others, he fails to differentiate between the objects toward which the thoughts of others are directed and those which are the focus of his own concern. The young adolescent, because of the physiological metamorphosis he is undergoing, is primarily concerned with himself. (p. 91)

In spite of knowing this, I was surprised to see the extent to which this selfcentredness affected their ecological understandings and beliefs. 
However, learning about their assumptions and misconceptions was not nearly as surprising as was the realisation that $I$ actually fostered these beliefs through my own teaching! I realised that many of my previous environmental education lessons were reinforcing some of these beliefs. First, I was supporting the idea that nature needed to be managed by community organisations concerned with hunting and recycling. With my new insights, I reviewed these activities. I realised that they did stress the need for management; not by pointing out that it is peoples' use of the environment that has caused the need for management, but by pointing out how nature would not function correctly without human intervention. Secondly, I realised that I was providing examples of environmentalists that I respected, however 'nerdy' and extreme they might be to an eighth-grader. Thirdly, I realised that I was supporting the notion that the environment was something outside of them. This occurred as I tried to tie geography into the science curriculum. Most of my lessons were developed around issues that centred on such far away places as the rainforests in Brazil or lakes in California.

By looking at the environment through their eyes, I realised that I would have to change my own teaching if I were truly going to help my students become people who are fit to be inhabitants of the planet. I also realised that I needed to examine some of my own assumptions about the best way to do this!

What are the Implications for My Teaching?

How Will These Actions Make Life Better?

Every day we make decisions based on our beliefs about the world and our role in it. Unfortunately, many of those decisions have disastrous consequences to the environment and to us. Many of our environmental problems are the result of our misguided assumptions, not from hatred or lack of concern for the Earth. My research confirmed that my students had such assumptions. The research process I went through allowed me to narrow my focus to some of these specific assumptions - assumptions that, if left unquestioned, could influence these adolescents' decisions, now and in the future.

I came to the conclusion that I had to change several things about how I approach environmental education in the middle school. For help, I returned to the literature, this time with a narrower focus. Through my new understandings and readings, I decided to create an environmental education classroom that was more authentic, integrated, holistic and accessible for middle level students.

First, I decided that my environmental lessons would centre on the students' community. I now understood that in order to reinforce the idea that they live in the environment, not beside it, I had to emphasise their own environment. As Bowers points out, students need to recognise that the 
person is an interactive member of a natural environment. I realised that they don't see themselves in interaction with the environment when I teach them that the environment exists in the rainforests of South America or Africa. Secondly, my future environmental lessons will be more integrated. They will use Mathematics to collect, analyse and interpret environmental data as a basis for drawing conclusions, as opposed to basing conclusions on sometimes misguided assumptions. In addition, the lessons will be integrated with social studies in order to help them understand their own subjectivity. Thirdly, the curriculum would be centred on unifying themes related to patterns and cycles. 'Life on Earth is an interactive web, not a hierarchy' (King, 1989, p. 19). I will emphasise that the environment has its own checks and balances. Fourthly, I will make environmental education more accessible for all students by incorporating examples of people with whom adolescents could relate as well as admire.

Changing the way I approach environmental education is an ongoing process. I took the first step by revamping a unit that I had planned. The unit centred on the park that was approximately one mile from the school. We explored the predator/prey relationships within that park. Next, the class learned about the water, nitrogen and oxygen cycles within the context of that setting. Overall, they learned how this environment was self-monitoring. We then explored the environmental issues that affect the park. Several park rangers, members of their own communities, work with the students as they learned about the park and, specifically, the stream life. Next, we went to the park to collect data on the quality of the stream. In the final assessment they completed a large-scale picture of themselves in the park that included a predator/prey relationship, a diagram, and written explanation of how they and the animals in that scene were a part of the water/nitrogen/oxygen cycles. They also explained how human influences were affecting all life within that system.

The cycle of trying out new ideas, observing and listening to my students, and reflecting on their learning and my own teaching continues...

\section{Learning to Look at Action Research through the Eyes of My Students}

I (Joanne) had been teaching research courses related to research and teaching for several years and while I was very interested in action research (actually mentoring many students through the action research process), the difference between teacher research and action research was not clear in my mind. Gayle's commitment to making her students partners in the research process and educating students to be partners with the environment taught me the difference. While there are many forms of teacher research, action research is a special form of research that may be carried out by teachers who are not only interested in understanding, but also changing their teaching to make it more in line with their values. While teacher research may have a variety of purposes, the basis of action 
research is its ethical commitment to creating democratic relationships with students. Finally, action research involves reflecting on one's own professional and personal role in the classroom. Without such critical self-reflection, we as teachers may interpret our classrooms and make decisions based on our own unquestioned assumptions.

As I worked with Gayle to problematise her own assumptions about how best to understand her students' perspectives, I realised that I, too, needed to problematise my assumptions about ways to be a critical colleague. At first, Gayle looked to me for guidance about how do an action research study, but eventually, I found myself learning from her. As she grew more confident in her own abilities and insights, she began to challenge me. From statements such as 'How should I analyse all of these tapes?' to 'There is NO WAY to analyse all of these tapes and still be an effective classroom teacher'. I began to wonder how many studies I had stifled by imposing the rigors of academic research on teachers.

Understanding the nature of research 'methods' is another area that underwent transformation as I talked with Gayle about how she would gather data. As with other students, I happily provided Gayle with a list of data collection 'tools' for documenting her study. However, what I provided her was only a mechanical approach to research without its action research soul. She brought these 'methods' to life by her own purposes. Conducting student focus group interviews became more than a 'method' of data collection. Using her creativity and commitment to partnership with her students, the focus group interview and student journal became a way to mutually develop an understanding of the student perspective. Her own journal became a vehicle for self-reflection on the social, moral and academic consequences of her actions as a teacher, as well as a way to question (and ultimately affirm) her belief in the purposes of environmental education. Data analysis, too, was driven not only by 'rules' and 'procedures', but a need to discover, along with her students, those assumptions that were shaping her students' words and actions.

As teacher educators, we want our students to problematise their own practice through critical inquiry. We want them to be skeptical of the taken-forgranted assumptions that underlie their teaching. This, we believe, is the path to change. How to nurture this inward looking and questioning stance, however, is problematic for us. To point out faulty thinking often results in resentment. An attitude of complete acceptance may not provide the impetus for critical self-reflection. Neither of these approaches have proven particularly useful in the past. As her critical colleague, however, I simply asked her to consider what values drove her to teach and to consider those values in all aspects of the research process. The irony that unfolded - that she was in fact contributing to her students' misunderstandings - was not one that either of us could have predicted. I began to wonder in what ways I, too, might have contributed to student misunderstanding - in this case of action research as a mechanical, rather than a living process of inquiry. As I 
began to see myself as an action researcher, trying to understand how a classroom teacher makes sense of action research, rather than a teacher of action research, I saw Gayle become increasingly confident in her own thinking. It was through this realisation that I ventured into an action research study of my own teaching.

\section{The Paradox}

The paradox, of course, is that by looking through the eyes of our students, we become more conscious of our purposes, our own unquestioned assumptions, and ourselves. By focusing on how our students see the world, we may see our own world with new eyes. A poem by Yevgeny Yevtushenko summarises our own insights about this paradox.

If we see people differently Than we saw them before, if we discover something new in them, then that means it surfaced first in ourselves.

From Zima Junction (1995)

Our own development as scholars of our teaching has been enhanced through this interactive process of teaching, observing the consequences of our actions and reflecting in collaboration with one another. We have each grown in our awareness of student voice and have become even more convinced of the importance of voice in empowering our students and ourselves.

\section{Correspondence}

Joanne Arhar, Department of Teaching, Leadership and Curriculum Studies, Kent State University, Kent, OH 44242-0001, USA

(jarhar@kent.edu).

\section{References}

A Guide to Curriculum Planning in Environmental Education (1985) Wisconsin: Department of Instruction.

Arhar, J. M., Holly, M. L. \& Kasten, W. (2001) Action Research for Teachers: traveling the yellow brick road. Columbus: Prentice Hall.

Bowers, C. A. (1993) Education, Cultural Myths, and the Ecological Crisis: toward deep changes. Albany: State University of New York Press.

Capra, F. (1996) The Web of Life. New York: Anchor Books.

Dewey, J. (1964) John Dewey on Education: selected writings. New York: Modern Library. 
King, Y. (1989) The Ecology of Feminism and the Feminism of Ecology, in J. Plant (Ed.) Healing the Wounds: the promise of ecofeminism. Philadelphia: New Society Publishers.

Elkind, D. (1981) Children and Adolescents: interpretive essays on Jean Piaget. New York: Oxford University Press.

Orr, D. W. (1992) Ecological Literacy: education and the transition to a postmodern world. Albany: State University of New York Press.

Quinn, D. (1992) Ishmael. New York: Bantam Books.

Tom, A. (1984) Teaching as a Moral Craft. New York: Longman.

Whitehead, J. (1989) Creating a Living Educational Theory from Questions of the Kind, 'How Do I Improve My Practice? Cambridge Journal of Education, 19, pp. 41-52. 